\title{
CONTROVERCY IN THE EVOLUTION OF THE WORLD AND EUROPEAN FINANCIAL REGULATION
}

\author{
Professor PhD Alexandru Olteanu \\ Ph D Mădălina Antoaneta Rădoi (Olteanu) \\ Nicolae Titulescu University
}

ABSTRACT: The financial regulation structures are linked to traditions and differ from one country to another. The financial revolution, and in Europe, the creation of unique market of the financial services launched again debates over the suitability of the regulation structures.

5-10 years ago, the debates were quartered over the virtues, especially on the disadvantages that the self-regulation system shows vs. the regulation practiced by the public organisms within the law provisions. The debate is based now on types of problems: the role of the central bank and the problem of the specialization.

Regarding the role of the central bank, there are arguments if the central bank is the proper authority to supervise banking and act in accordance with it, as a councilor, after all.

Regarding the specialization, there are arguments if a super or hiper authority, authorized to regulate all the types of services and financial institutions is more adequate than the regulation by specialized agencies.

At the level of the European Union, there is an extra problem if the national authorities must keep the prerogative of financial services supervision, however in accordance with the basic principle of the economic and monetary integration, or if, on the contrary, it is better to form a European supervision authority for the financial services.

Key words: globalization; financial regulation; financial supervision; financial markets efficiency, financial conglomerates.

JEL codes: $F 36$

\section{REGULATION STRUCTURES AT THE GLOBAL LEVEL}

At the level of status, action and institutional construction, England played a pioneer role, when in 1997 Tony Blair's Labor Party created the Financial Services Authority, as a unique financial services regulation authority, stating also the role of the Central Bank in banking supervision (by exonerating the English Bank of this prerogative) and also the virtues, especially the defaults of the unique regulation towards the specialized regulation.

Austria, Denmark and Sweden also have unique regulation authority. Two countries Belgium and Finland - have joint organisms for banks and investment services; other seven countries have separated institutions, which regulate the investment services. In France, the main regulation organism is the Committee for Stock Exchange Operations, the so-called COB, which shares responsibility with other two organisms: The Financial Market Council, a regulation organism, which supervises market transactions and The Banking Committee, which supervises the banking activity. Germany, which at present has special authorities for banking, investment services, insurance, expressed its wishes to adopt the unique regulation authority system. In France, too, there are talks to merge the regulation authorities, but the French authorities sustain firmly the heads regulation model, respectively for the circumspection regulations and wholesale (professional 
financial transactions) and the retail market regulations, on which the financial products are sold to the consumers.

Among the European Union countries, Hungary was the first, in the first part of 2001, to proceed to the merging of the three regulation agencies within the Hungarian Financial Supervision Authority.

Outside Europe, there are regulation and supervision super authorities in Japan, South Korea, China, Hong Kong, Taiwan, and in North America - Canada.

In the USA, the regulation system, which has not changed essentially since 1934, is characterized by specialization and fragmentation. The capital markets are regulated by SEC (Security and Exchange Commission). But the other components of the financial services sector are under the authority of more regulation and supervision state bodies. The so-called Office of The Comptroller of The Currency is the one that watches over banks, but also The Federal Deposit Insurance Corporation, The Federal Reserve Board (The Central Bank) and The Bank Boards from different sates. As for the insurance companies, they are regulated and supervised by the states insurance Boards.

\section{THE CENTRAL BANK AND THE BANKING SUPERVISION}

According Karel Lannoo (1998) from the Brussels European Centre of Political Studies (CEPS), the debate this problem should be started from the role of the central bank in insuring the stability of the financial systems and prevention of the contagious systemic crisis.

The pro argument: the practicing of the regulation and banking supervision functions by the central bank can contribute to the general financial stability insurance, inclusively in the process of bank saving.

The con argument: the monetary policy and banking supervision functions generate interest conflicts, endangering the price stability and stressing the moral risk.

Both regimes are equally illustrated in the European Union. According to Goodhaad and Schoenmaker (1995), the matter must be regarded not as an abstract theoretical exercise, but in the context of financial structure and banking particularity from each country. An analysis of the bankruptcies from the last two decades shows a more frequency in countries with a separate regime, than in the ones with mixed regimes. Their conclusion is that the banking saving operations are more likely to happen in mixed regimes.

In the banking sector there is an increase in the role of the self regulation, and there would be an over increasing agreement on the idea that the government and not the central bank, should bear the responsibility of the financial support in extreme cases. This is the case of the last decade experiments in Norway, Sweden and France, because they turned to the public fund financing, transferred to the taxpayer.

\section{TWO VISIONS OVER THE FINANCIAL MARKETS REGULATIONS}

We consider that the approaches of the regulation problems group around two concepts:

I. The efficiency of the financial markets and

II. The imperfection and the instability of the financial markets (Plihon, 2001), concentrated in the following table. 
Table no. 1

\begin{tabular}{|c|c|c|}
\hline & $\begin{array}{l}\mathbf{1}^{\text {st }} \text { paradigm: The efficiency of the } \\
\text { financial markets }\end{array}$ & $\begin{array}{l}2^{\text {nd }} \text { paradigm: The imperfection and } \\
\text { the instability of the financial markets }\end{array}$ \\
\hline $\begin{array}{l}\text { The place of } \\
\text { the public } \\
\text { supervision }\end{array}$ & $\begin{array}{l}\text { Supervision must be limited to } \\
\text { following the transparency rules. } \\
\text { Public supervision must be } \\
\text { constrained if it affects the market } \\
\text { discipline play. } \\
\text { The disfunctions of the market come } \\
\text { mostly from the excess than from the } \\
\text { insufficiency of the public } \\
\text { supervision. }\end{array}$ & $\begin{array}{l}\text { Supervision is a necessary } \\
\text { completion of the market discipline. } \\
\text { The need to interfere from the outside } \\
\text { of the market. } \\
\text { Public supervision is necessary to } \\
\text { compensate for the markets failure. }\end{array}$ \\
\hline $\begin{array}{l}\text { The market } \\
\text { discipline }\end{array}$ & $\begin{array}{l}\text { The market discipline must be the } \\
\text { main way to regulate markets. } \\
\text { All obstacles that alter the market } \\
\text { discipline play must be eliminated. } \\
\text { Grants and public warranties. } \\
\text { Deposits insurance must be limited to } \\
\text { monetary deposits. } \\
\text { The development of the subordinated } \\
\text { debt. } \\
\text { The financial freedom of the emerged } \\
\text { countries must be simulated. }\end{array}$ & $\begin{array}{l}\text { The market discipline is a necessary } \\
\text { condition, but not enough for the } \\
\text { proper function of the markets. } \\
\text { The market discipline must be } \\
\text { completed by: } \\
\text { - penalties from the } \\
\text { regulation authorities; } \\
\quad-\text { early actions. correction } \\
\text { Financial freedom of the merged } \\
\text { countries must be followed by the } \\
\text { construction of an effective public } \\
\text { supervision system. }\end{array}$ \\
\hline $\begin{array}{l}\text { The role of the } \\
\text { transparency }\end{array}$ & $\begin{array}{l}\text { Transparency, the necessary and } \\
\text { sufficient condition for the market } \\
\text { discipline exercise and for the } \\
\text { informational efficiency of the } \\
\text { markets. } \\
\text { The need that the necessity to } \\
\text { information to be expanded to all the } \\
\text { participants - banking or non-banking } \\
- \text { at the financial markets. The } \\
\text { financial crises from the emergent } \\
\text { countries are due to the lack of } \\
\text { transparency of the local financial } \\
\text { institutions. }\end{array}$ & $\begin{array}{l}\text { The following of the regulation rules } \\
\text { is not sufficient: } \\
- \text { the opacity - the } \\
\text { fundamental } \\
\text { characteristic of the } \\
\text { banking agency - } \\
\text { imposes public } \\
\text { supervision; } \\
- \text { the exclusive accent } \\
\text { on transparency } \\
\text { ignores the mimesis } \\
\text { and other } \\
\text { compartments on } \\
\text { resulted from the } \\
\text { collective psychology } \\
\text { of the financial } \\
\text { markets. }\end{array}$ \\
\hline
\end{tabular}

We must keep in mind that the financial regulation entails three functions:

- the behaviour rule setting;

- the control of the rule application (monitoring);

- the cautious supervision, whose objective is risk prevention.

The financial regulation and supervision have a caution micro dimension (the authorisation of the public financial services performing; supervision according to the continuous report 
documents and on the spot control) and a new macro cautious dimension, regarding prevention and crises fight (risk limitation and insurance of good protection against them).

\section{SUPERVISION AUTHORITY THROUGH CONSOLIDATED REGULATION OR THROUGH SPECIAL REGULATION?}

The arguments of the scale economies, some political and practical advantages and especially the fact that this kind of regulation is the best adjusted to the financial conglomerate forming tendencies, offering the entire range of financial services and products plead in favour of the consolidated regulations.

Table no. 1

\begin{tabular}{|c|c|}
\hline \multicolumn{2}{|c|}{ Pro arguments } \\
\hline A unique authority of financial regulation & An authority of financial regulation \\
\hline -one-stop measure in order to authorise & -easier organization \\
\hline $\begin{array}{l}\text {-expertise concentration and scale economies } \\
\text { (e.g. by merging the authorisation functions) }\end{array}$ & -clearly defined competences \\
\hline -lower supervision costs & -closer to regulation activities \\
\hline $\begin{array}{l}\text {-more adjusted to the financial sector evolution } \\
\text { by financial conglomeration }\end{array}$ & $\begin{array}{l}\text {-more adjusted to the differences regarding the } \\
\text { risk and the nature of the financial activities, a } \\
\text { more clear focus for the objectives and the } \\
\text { regulation good sense }\end{array}$ \\
\hline $\begin{array}{l}\text {-cooperation insured by the supervision forms: } \\
\text { a coordinator for the conglomerate supervision }\end{array}$ & -a better knowledge of the regulation activities \\
\hline $\begin{array}{l}\text {-the absence of the arbitration need regarding } \\
\text { the regulation }\end{array}$ & -a more discreet presence \\
\hline -a more transparent form for the consumer & $\begin{array}{l}\text {-a bigger tendency towards the objective based } \\
\text { tendency }\end{array}$ \\
\hline
\end{tabular}

Source: Karel Lanno

The objective basis supervision. A way to adjust to the forming of conglomerates tendency is as supervision to become more focused on objectives and to proceed separately on matters regarding:

- stability, solvency;

- business behaviour: informing and transparency, practice based on honesty and fairplay, equality of the market participants.

\section{THE FINANCIAL REGULATION PROBLEM AT THE EUROPEAN UNION LEVEL}

The creation of a unique financial services market is supported by three pillars:

- a minimum homogeneity of the different national markets as an affect of the European regulation provision implementation regarding banking, financial investment services and insurances, able to allow the mutual recognition of the tools, of the financial services and of such services providers;

- "unique passport" principle, meaning the viability of the offered authorization in a country to establish subsidiaries in any member country or to provide trans border services;

- responsibility of the host country regarding supervision. 
The commission, reacting at the member countries disobedience, set a Forum of the Transferable Securities European Committee (FESCO) with the mission of promoting cooperation among the regulation authorities for the transferable securities markets.

FRESCO doesn't have the official status, but must work in accordance with a consensus, and cannot issue compulsory recommendations. Therefore, soon after the euro was released, the European leaders adopted, at the Lisbon summit from Mars, 2000, the Action Plan for the financial services (FSAP) initiated by the Commission, which recommended 42 measures in order to rationalize the wholesales and retail financial markets, with implementation terms up to 2005, whose achievement elongated to 2007.

The present points of view are the following:

Most of the member states agree with the idea of a unique regulation forum, others, as France, support an integrated system, but a dual one. In accordance with the same considerations, the idea of a pan European regulation forum is regarded as a solution for the present chaos from this field. Other countries continue to prefer the national authority and competition system between different jurisdictions.

The Lamfalussy group, the President of the Wise Men Committee over the transferable securities European markets regulations identified numerous and important gaps in the European laws and proposed a series of priory measures, which were adopted and came into force at the end of 2003:

- a unique prospect for the issuers, with an obligatory preliminary registration system;

- the modernising of the demands to subscribe for the share and the introduction of a clear distinction between the share admission and the transaction admission;

- the generalization of the mutual recognition principle for the wholesale markets, including an accurate definition of the professional investor;

- the modernizing and the development of the financial investment rules for the investment funds and pension funds;

- the IAS adoption (international accountancy standards);

- the unique passport for the confirmed stock markets and the application of the principle that supervision is assured by the host country.

The Lamfalussy group noticed that in the European Union there are about 40 public organisms which deal with the supervision and the regulation of the transferable securities markets. The components are mixed and the responsibilities are different. They sum up that "The result at the European level is the fragmentation and, often, the confusion".

\section{THE UNIFICATION OF THE FINANCIAL SERVICES REGULATION AND SUPERVISION IN ROMANIA}

The distinction between the wholesale and retail markets, supported by France and applied in Italy, is considered to be fertile and could be kept in consideration in a later stage of evolution in the Romanian capital markets, if the situation asks. But for the moment, the way to England should be kept open and should be followed in our area by Hungary. Unitary standards application and setting would create better conditions for the financial services evolution and a more effective supervision achievement.

\section{THE IMPETUOUS EVOLUTION OF THE FINANCIAL RESEARCH}

The profound transformations of the financial markets in the last two decades, has as a major feature the fact that one of its pillars was made by the passing through achieved at the 
theoretical level at which a series of well-known economists and money specialists, some of them being awarded with the Nobel Prize for economics.

The diversity of the financial assets and the risk reduction while the title portfolio is increasing are linked to Harry Markowitz contributions, starting with the Ph. D. work in 1952. For these contributions, which revolutionized the way and the management practices of the individual and institutional portfolios, he was awarded with the Nobel Prize for economics in 1990.

The arbitration technique derived advantages from Franco Modigliani and Marton Miller's important contributions. They proved that the market value of a company is independent of the way in which the company finances its capital and takes place especially from the cash flow. A company in great debts, but also with an important cash flow can have a greater value on the market than a company that shows precaution when it comes to reference to external resources and debts.

Modigliani and Miller are the founders of a new economic-financial subject, appeared at the junction between the pure economic theory and the financial conduct of the companies. At the practical level, their contributions stand at the basis of the action of the investment companies, which follow earnings from the arbitration operations.

The passive administration based on financial title portfolio subscripts is based on the effectiveness theory of the capital markets.

Ragan and Zingles (1998) focus on the techniques by which the financial development stimulates the economic growth. They test empirically the idea that under the conditions of some evolved financial systems the companies and the branches, which depend on financing by attracted means, are advantageous (new companies and branches).

Their conclusion is that the former previous evolution of the capital markets facilitates in a great amount their former post growth of these companies and branches. As they are a source of new ideas, the financial evolution stimulates the innovation and therefore the economic growth. They demonstrate especially the importance for a development growth of the risk capital market.

Therefore, we can conclude that a very developed capital market represents for a country a comparative source of evolution in branches, which are more dependent on an external financing.

Levine and Zervos also check empirically if the development levels of the stock markets (liquidity, dimension, volatility and integration with the world capital markets) are correlated with the ratio presented in the next economic growth, capital accumulation, and productivity and saving ratio growth. They analyze the statistics from 47 countries from 1976 to 1993. Their conclusion shows that these correlations are positive and important. The financial factors appear as an integrant part of the growth process.

In 2000, a study developed by three economists analyzes data from 63 countries regarding the period 1960-1995, in order to depict the influence of the financial development over the economic growth and over its sources. They follow the influence of this type of development over the saving ratio, the cash capital accumulation and the total increase of the productivity at the factor level. These authors do not notice a strong positive correlation with the cash capital accumulation or the private saving ratio, but find such a correlation when it comes to the real increase of the GNP on inhabitant and the productivity increase at the factor level.

\section{CONCLUSIONS}

The financial supervision authority although evolved plans: consolidate regulation and special regulation, it still wins a lot: the idea we are supporting of objectives based supervision (e.g. stability, solvability, business conduct etc.). Within the EU the existence of a large number of regulation and supervision organisms led to the conclusion of fragmentation and sometimes confusion.

The strong development of financial power research based on mechanisms by which the financial evolution stimulates the economic growth and financing sources has won a lot. 


\section{References:}

1. Ferrandon, Benoit, "Regulation du systeme financier national et international", Bourse et marches financiers, nr. 301, 2000 ;

2. Groups of Thirty, "Global Institutions, National Supervision and Systemic and National Responses", Washington DC, 1999;

3. Kuhn, Robert Lawrence, "Mortgage and Asset Securization", Business One IRWIN, Homewood, Illinois, 1994;

4. Lannoo, Karel, "A Decade of Financial Market Liberalistation in the EU", CEPES, Brussels, 1998;

5. Olteanu, Alexandru; Olteanu, Mădălina Antoaneta; "Piețe de capital”, Ed. Dareco, Bucureşti;

6. Olteanu, Alexandru; Olteanu, Florin Manuel; "Managementul portofoliului şi al riscului pe piața titlurilor financiare", Ed. Dreco, Bucureşti, 2003;

7. OECD, "Institutional Investors in the New Financial Landscape", OECD, Paris, 1998;

8. OECD, "OECD. Principles of Corporate Governance", OUS-SG/LG, (99) Aprilie 5, 1999;

9. Ragan, Raghiran G.; Zingales, Luig; "Financial Dependence and Grow", American Economic Review, nr. 88, June, 1998;

10. *** - The Committee of WiseMen, "Final Report on the Regulation of the European Securities Markets", European Union, Brussels, February, 15, 2001;

11. *** - "A survey of corporate finance", The Economist, January, 17 $7^{\text {th }}, 2000$;

12. *** - "A survey of European business", The Economist, April 29 $9^{\text {th }}, 2000$;

13. *** - "A survey of global equity markets", The Economist, May $5^{\text {th }}, 2000$;

14. *** _ "A survey of international business", The Economist, April 17", 1999 ;

15. *** - "A survey of online business", The Economist, May $20^{\text {th }}, 2000$;

16. $* * *$ - Business Week, November 12, 2000. 